\title{
Characterization of Colombian Clay and Its Potential Use as Adsorbent
}

\author{
Iván Fernando Macías-Quiroga, ${ }^{1}$ Gloria Inés Giraldo-Gómez, ${ }^{2}$ \\ and Nancy Rocío Sanabria-González $\mathbb{D D}^{1}$ \\ ${ }^{1}$ Departamento de Ingeniería Química, Facultad de Ingeniería y Arquitectura, Universidad Nacional de Colombia Sede Manizales, \\ Campus La Nubia, Km 7 Vía al Aeropuerto, AA 127, Manizales, Colombia \\ ${ }^{2}$ Departamento de Física y Química, Facultad de Ciencias Exactas y Naturales, Universidad Nacional de Colombia Sede Manizales, \\ Campus La Nubia, Km 7 Vía al Aeropuerto, AA 127, Manizales, Colombia
}

Correspondence should be addressed to Nancy Rocío Sanabria-González; nrsanabriag@unal.edu.co

Received 18 July 2018; Revised 18 September 2018; Accepted 4 October 2018; Published 24 October 2018

Academic Editor: Vera R. Constantino

Copyright (C) 2018 Iván Fernando Macías-Quiroga et al. This is an open access article distributed under the Creative Commons Attribution License, which permits unrestricted use, distribution, and reproduction in any medium, provided the original work is properly cited.

\begin{abstract}
This paper presents a mineralogical and physicochemical characterization of a Colombian clay found in an area with the greatest exploitation potential of smectites and possible use as an adsorbent for the removal of chromium. The clay was characterized by using X-ray diffraction (XRD), cation exchange capacity (CEC), X-ray fluorescence (XRF), Fourier transform infrared spectroscopy (FT-IR), thermal analysis (TGA/DSC), and nitrogen adsorption at $77 \mathrm{~K}$. The homoionized clay was used as an adsorbent for the removal of $\mathrm{Cr}$ (III) in an aqueous solution. The homoionized clay was modified with hexadecyltrimethylammonium bromide (HDTMA-Br), and the organoclay obtained was evaluated for the adsorption of $\mathrm{Cr}(\mathrm{VI})$ in aqueous solution. The XRD analysis showed that the clay from Armero-Guayabal is primarily constituted by smectite ( $48 \mathrm{wt} \%$ ) followed by quartz mineral (21 wt\%). The chemical analysis of bulk clay showed that the predominant oxides are $\mathrm{SiO}_{2}$ (55.81 wt\%), $\mathrm{Al}_{2} \mathrm{O}_{3}\left(16.25 \mathrm{wt} \%\right.$ ), and $\mathrm{Fe}_{2} \mathrm{O}_{3}(7.51 \mathrm{wt} \%$ ), and the nitrogen adsorption indicated that the bulk clay has a specific surface area of $45.1 \mathrm{~m}^{2} / \mathrm{g}$. Homoionized clay and organoclay achieved $\mathrm{Cr}(\mathrm{III})$ and $\mathrm{Cr}(\mathrm{VI})$ removals greater than $85.05 \pm 2.04 \%$ (pH between 3 and 4 ) and $82.93 \pm 1.03 \%$ (pH between 3 and 5), respectively, proving the potential of these materials for the removal of heavy metals in an aqueous solution.
\end{abstract}

\section{Introduction}

The term "clay" has been defined as a naturally occurring material primarily made of fine-grained minerals (clay minerals), being generally plastic at appropriate water contents and hardening when dried or fired [1]. Phyllosilicate clay minerals are the main constituent of clays [2]. They are of great interest for the scientific community due to their potential industrial applications in many areas $[2,3]$. Clay minerals are generally classified into three layer types (1:1, 2:1, and 2:1:1) based upon the number and arrangement of tetrahedral and octahedral sheets in their basic structure. These are further separated into five groups (kaolinite, mica, smectite, vermiculite, and chlorite) that differ with respect to their net charge. Smectite is the name used for a group of phyllosilicate mineral species, the most important of which are montmorillonite, beidellite, nontronite, saponite, and hectorite [4].

Montmorillonite is a 2:1 phyllosilicate that belongs to the group of smectites and it is the main component of bentonite clay. Bentonite is a material derived from the chemical alteration of a glassy material of igneous origin emitted from volcanoes (usually tuff and/or volcanic ash) [5, 6]. It was named by Wilbur C. Knight in 1898, and the name is derived from a site located in Fort Benton, United States [7]. Bentonite is currently an important material due to the large number of applications in the food industry $[8,9]$, paints [10], pharmaceutical industry [11, 12], and wastewater treatment $[13,14]$ and as a catalyst $[3,15-17]$.

World bentonite production has increased from 2008 to 2014, growing from 1.57 to $1.62 \times 10^{7}$ metric tons according to the British Geological Survey report $[18,19]$. The exploitation 


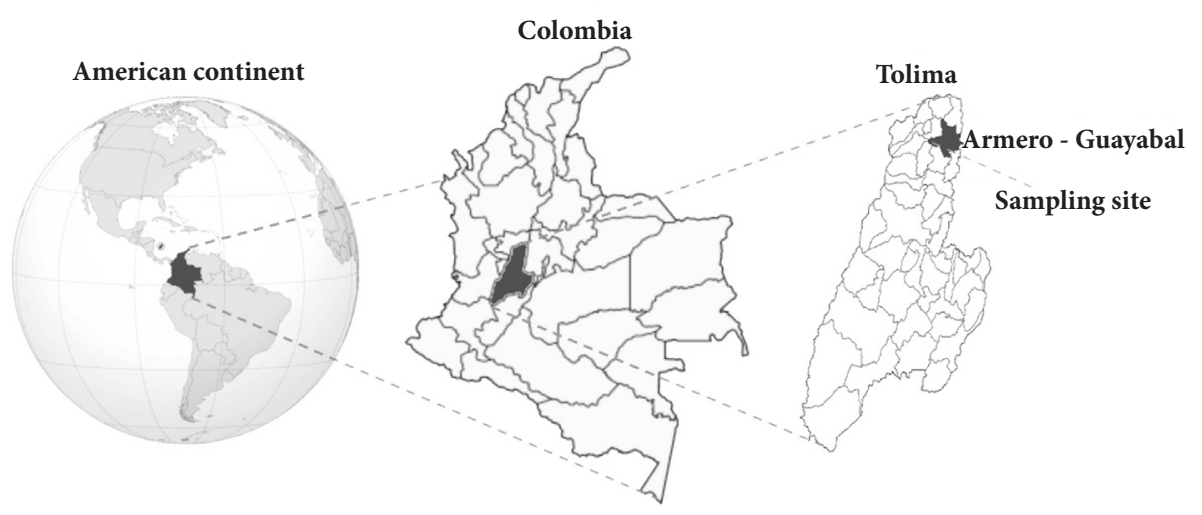

Figure 1: Geographic localization of clay deposit.

of bentonite in Colombia between 2009 and 2014 has risen from 8.5 to $9.0 \times 10^{3}$ metric tons $[19,20]$, Valle del Cauca region being the main producer. Colombia has a strong pottery tradition in which clays have been used to make roof tiles, pots, and other utensils. It is necessary to explore new industrial uses because the country has an estimated $1.1 \times 10^{9}$ metric tons in smectite clays deposits [21].

In Colombia, deposits with smectites resources have been identified for possible exploitation, mainly in the departments of Valle del Cauca and Tolima $[22,23]$. The deposits of Valle del Cauca have been commercially exploited since the early 70's. There are several published studies on the application of bentonites from Valle del Cauca, especially modifications via pillarization with application in oxidation reactions [15, 17, 24-27]. Particularly, from a study of the Colombian Geological Survey (CGS) in 2004, it is known that deposits of smectite clays are found in Lérida, ArmeroGuayabal, and Mariquita [22], all of them municipalities at the north of Tolima department (Central-west Colombia). 32 clay samples were analyzed by CGS, finding that smectite clays are present in rocks of paleogenic and neogenic volcanic origin. Besides, smectite percent in clays was estimated between $3.2 \%$ and $56.6 \%$ for the samples studied. However, bentonites from northern Tolima have been little studied, and their commercial exploitation has focused on additives for animal concentrate and cat litters.

The abundance of bentonite and its cation exchange properties make this low-cost material a strong candidate as an adsorbent for the removal of heavy metal from wastewater [28]. The chemical modification of clay mineral through the use of cationic surfactant to generate organoclays [29] has applications in environmental remediation [30]. Additionally, these materials have shown particular properties for the adsorption of many emerging pollutants, becoming a potential alternative for the remediation of micropollution $[29,31]$.

This study carried out the physicochemical and mineralogical characterization of Armero-Guayabal clay, and it assessed its potential use as an adsorbent for the removal of chromium from aqueous solution.

\section{Materials and Methods}

2.1. Bulk Clay Collection. Bulk clay was collected from a deposit in Armero-Guayabal, a municipality in the north of the Department of Tolima, in the central-western part of Colombia (latitude $4^{\circ} 58^{\prime} 4.44 \mathrm{~N}^{\prime \prime}$, longitude $-74^{\circ} 52^{\prime}$ $52.32 \mathrm{O}^{\prime \prime}, 366 \mathrm{~m}$ a.s.1.), as shown in Figure 1. The sample was collected from a mine in a zone affected by the weathering of volcanic rocks deposited in recent rock units (near the area of El Ruiz volcano) [22, 32]. The Armero-Guayabal deposit has been exploited since 2011 by the company Gea Minerales S.A.S., and it is estimated to have ore reserves of around 1.2 million tons. The samples were collected in the mine area at the same thickness of the clay layer ( 3 to $5 \mathrm{~m}$ in the vertical section), distanced by $2 \mathrm{~m}$ in the horizontal section. 10 bulk samples ( $5 \mathrm{~kg}$ each) were collected using hoe and shovel and then were packed in plastic bags with air tight seal. Bulk samples were dried at $105^{\circ} \mathrm{C}$ until reaching a constant weight. Then, they were mechanically ground, powdered in a ball mill, and passed through a 100 mesh. Equal proportion of bulk samples $(1 \mathrm{~kg})$ was mixed and homogenized to form a single representative sample that was used for all the tests.

2.2. Separation of the Clay Fraction. The particle size separation of the clay fraction was performed by gravitational sedimentation based on Stokes' Law [33, 34]. $50 \mathrm{~g}$ of the powder sample was suspended in $5 \mathrm{~L}$ of distilled water. The sample was disaggregated for approximately 20 minutes with a magnetic stirrer and transferred to a graduated cylinder to sediment gravitationally. To obtain the fraction lower than $2 \mu \mathrm{m}$, the suspension was allowed to settle for $16 \mathrm{~h}$ and the first $20 \mathrm{~cm}$ of the suspension removed. Subsequently, the suspension was centrifuged at $5000 \mathrm{rpm}$ for 15 minutes to recover the clay fraction, which was dried at $60^{\circ} \mathrm{C}$, ground, and sieved in 100 mesh. This sample was used for mineralogical analysis. The clay fraction can also be called purified clay.

Although the gravimetric sedimentation is the most used method for the separation of the clay fraction $(<2 \mu \mathrm{m})$ [33], this methodology requires well diluted clay suspensions and 
TABLE 1: Further tests for detailed identification of the clay [36].

\begin{tabular}{lcc}
\hline Treatment 1 & Treatment 2 & Treatment 3 \\
\hline Saturation with $0.5 \mathrm{M} \mathrm{LiCl}, 24 \mathrm{~h}, 25^{\circ} \mathrm{C}$ & Saturation with $0.5 \mathrm{M} \mathrm{KCl}, 24 \mathrm{~h}, 25^{\circ} \mathrm{C}$ & Saturation with $0.5 \mathrm{M} \mathrm{MgCl}_{2}, 24 \mathrm{~h}, 25^{\circ} \mathrm{C}$ \\
\hline Calcination at $300^{\circ} \mathrm{C}, 2 \mathrm{~h}$ & Heating a $100^{\circ} \mathrm{C}, 2 \mathrm{~h}$ & \\
Saturation with vapour glycerol, $24 \mathrm{~h}, 35^{\circ} \mathrm{C}$ & $\begin{array}{c}\text { Saturation with vapour ethylene glycol, } \\
24 \mathrm{~h}, 35^{\circ} \mathrm{C}\end{array}$ & Saturation with vapour ethylene glycol, $24 \mathrm{~h}, 35^{\circ} \mathrm{C}$ \\
\hline
\end{tabular}

long times making it not viable for industrial purposes. Therefore, for the adsorption tests, the clay was purified using a simple method of dispersion of ground clay in water with addition of sodium hexametaphosphate and centrifugal separation [35]. In a beaker, $50 \mathrm{~g}$ ground powder bulk clay was suspended in $0.6 \mathrm{~L}$ of distilled water with $0.5 \mathrm{~g}\left(\mathrm{NaPO}_{3}\right)_{6}$ and then magnetically stirred for $24 \mathrm{~h}$. The supernatant of the dispersion was separated by centrifugation at $700 \mathrm{rpm}$ for $2 \mathrm{~min}$. The purified bentonite was obtained after centrifugation at $4700 \mathrm{rpm}$ for $5 \mathrm{~min}$, washed five times with distilled water, and dried at $60^{\circ} \mathrm{C}$ in an oven. The dried purified clay was ground and sieved in 100 mesh.

\subsection{Mineralogical and Chemical Characterization of the Clay.} The clay sample was analyzed both as random powder of the bulk material and as oriented mounts of the fraction < $2 \mu \mathrm{m}$ by using a LabX Shimadzu XRD-6000 diffractometer with $\mathrm{Cu} \mathrm{K} \alpha$ radiation (steps of $0.01^{\circ} 2 \theta$ and 2 s/step). The pattern of XRD was compared with X-ray reference patterns for the identification of the different minerals, using an X'Pert HighScore Plus software. Identification of mineralogical components of smectitic type was carried out applying the protocol established by Thorez [36] and Schultz [37]. The semiquantitative mineralogical analysis was based on the signal area ratio and the intensity of clay mineral (intensity factors) [38-40]. Relative proportions of the clay minerals were normalized to $100 \%$ [37, 41$]$.

The bulk clay dried at $60^{\circ} \mathrm{C}$ was ground in an agate mortar until the size of the largest particles was less than $38 \mu \mathrm{m}$ (mesh 400). The sample was introduced in the cavity of the sample holder to minimize preferred orientation of the particles. A glass slide was used to pack the sample into the cavity, just enough to create a smooth surface that would not deform during the rotation of the sample during XRD analysis [42].

Oriented mounts were prepared from the clay fraction $<2 \mu \mathrm{m}$. A few drops of the clay suspension $(600 \mathrm{mg}$ of clay in $5 \mathrm{~mL}$ of water) were smeared on a glass slide, which was left to dry at room temperature. The basic identification of the clay was made according to the position of basal reflection 001 in three patterns of X-ray diffraction: (i) natural sample, (ii) natural sample after solvation in the presence of vapor ethylene glycol for $24 \mathrm{~h}$ at $35^{\circ} \mathrm{C}$, and (iii) glycolated natural sample after heating at $500^{\circ} \mathrm{C}$ for $2 \mathrm{~h}$. In addition, the clay fraction $<2 \mu \mathrm{m}$ was saturated with $\mathrm{Li}^{+}, \mathrm{K}^{+}$, and $\mathrm{Mg}^{2+}$ solutions and the samples subjected to XRD after the treatments described in Table 1.

Chemical analyses of the bulk and clay fraction were accomplished by X-ray fluorescence using a Magix Pro Philips PW2440 instrument, with samples prepared as pearls. Total organic carbon was estimated by Multi N/C 3100 TOC analyzer (Analytik Jena, Germany) in a horizontal high temperature oven HT1300 for solid sample analysis equipped with a nondispersive infrared detector. The calibration was made with analytical grade $\mathrm{CaCO}_{3}$. The calculated error for this technique was $\pm 0.02 \%$.

For the Foster swelling test, bulk clay and clay exchanged by sodium were sieved in a 200 mesh and dried at $105^{\circ} \mathrm{C}$. Then, $2 \mathrm{~g}$ of dry sample was added in portions of $100 \mathrm{mg}$ at $10 \mathrm{~min}$ intervals for $3 \mathrm{~h}$ to $100 \mathrm{~mL}$ of a sodium lauryl sulfate solution $(1 \% \mathrm{w} / \mathrm{v})$ contained in a $100 \mathrm{ml}$ measuring cylinder. The samples were allowed to settle for $16 \mathrm{~h}$ before determining their volume. The test was carried out under the Colombian technical standard method NTC 2271 [43].

The cation exchange capacity (CEC) of bulk clay and clay fraction was determined with ammonium acetate. The sample was firstly ammonium exchanged; then the ammonium ions in the supernatant were deprotonated into ammonia with a sodium hydroxide solution and determined by distillation into a known amount of acid which was again titrated (Kjeldahl-method) [44].

Fourier transform infrared spectrometry (FT-IR) was recorded from samples pressed into pellets with $\mathrm{KBr}$ powder by using a Nicolet iS5 (Thermo Scientific).

The thermal analysis was performed in a STA 409 Netzsch instrument with a $75 \mathrm{~cm}^{3} / \mathrm{min}$ air flux and heating speed of $10^{\circ} \mathrm{C} / \mathrm{min}$.

Nitrogen adsorption-desorption isotherm of clay fraction was determined in a Micrometrics ASAP 2020 instrument at $77 \mathrm{~K}$ after outgassing the samples for $1 \mathrm{~h}$ at $90^{\circ} \mathrm{C}$ followed by $3 \mathrm{~h}$ at $400^{\circ} \mathrm{C}$ in a vacuum. The specific surface area $\left(\mathrm{S}_{\mathrm{BET}}\right)$ was measured by means of BET equation and the total pore volume was evaluated for nitrogen uptake at a relative pressure of 0.99 . Microporous specific surface area and micropore volume were calculated using the $t$-method of the Harking-Jura equation $[45,46]$.

2.4. Homoionization of Clay. $50 \mathrm{~g}$ of purified clay was dispersed in $5 \mathrm{~L}$ of $1 \mathrm{M}$ solution of $\mathrm{NaCl}$ by shaking for about $24 \mathrm{~h}$; then the supernatant was removed. This procedure was repeated to get the clay saturated with sodium. After the two exchanges with the $\mathrm{NaCl}$ solution, the clay obtained was washed with distilled water until reaching a conductivity lower than $10 \mu \mathrm{s} / \mathrm{cm}$, dried at $60^{\circ} \mathrm{C}$, and finally ground and sieved in a 100 mesh.

2.5. Synthesis of Organoclay. The organoclay was prepared with an ion exchange reaction between the clay homoionized with sodium and an organic cationic surfactant, hexadecyltrimethylammonium bromide (HDTMA-Br). The loading 
of $\mathrm{HDTMA}^{+}$surfactant was equivalent to 1.5 times the cation exchange capacity (CEC) for homoionized clay [47]. $20 \mathrm{~g}$ homoionized clay was added to $400 \mathrm{~mL}$ of distilled water and, to this suspension, $4.80 \mathrm{~g}$ of HDTMA was added. The mixture was stirred for $24 \mathrm{~h}$. The organoclay was then removed from the mixture by centrifugation and then washed several times with water until being bromide-free. Finally, the organoclay was dried at $60^{\circ} \mathrm{C}$, ground, and sieved in a 100 mesh.

2.6. Preliminary Tests of Chromium Adsorption. The effect of $\mathrm{pH}$ on the adsorption of $\mathrm{Cr}$ (III) on natural bentonite and $\mathrm{Cr}(\mathrm{VI})$ on organoclay was evaluated. The adsorption experiments were performed by using the batch method, suspending the clay ( $0.5 \mathrm{~g}$ clay or $0.2 \mathrm{~g}$ organoclay) in $50 \mathrm{~mL}$ an aqueous solution of chromium (Cr(III) or $\mathrm{Cr}(\mathrm{IV})$ ) at $50 \mathrm{mg} / \mathrm{L}$. Samples were shaken for $1 \mathrm{~h}$ at $200 \mathrm{rpm}$ at $20^{\circ} \mathrm{C}$. Standard solutions of Titrisol ${ }^{\mathrm{TM}} \mathrm{Merck}^{\circledR}\left(\mathrm{CrCl}_{3}\right.$ in $\left.\mathrm{HCl} 4.2 \%\right)$ and potassium dichromate $\left(\mathrm{K}_{2} \mathrm{Cr}_{2} \mathrm{O}_{7} 0.1 \mathrm{~N}\right)$ were used to prepare a synthetic wastewater which was diluted to $50 \mathrm{mg} / \mathrm{L}$ in order to carry out adsorption tests using the bulk clay and organoclay. The adsorbent was separated by centrifugation and supernatant solution filtered in a $0.22 \mu \mathrm{m}$ filter and then carefully transferred to glass flasks to determine the concentrations of chromium present in aqueous medium. The concentrations of chromium were measured by flame atomic absorption spectrometry (iCE 3500, Thermo Scientific, Germany), with an air-acetylene flame. All the tests were performed in triplicate.

$\mathrm{Cr}(\mathrm{III})$ and $\mathrm{Cr}(\mathrm{VI})$ adsorption isotherms were obtained by using a batch equilibration procedure. Adsorbent samples were balanced by shaking at $20^{\circ} \mathrm{C}$ with the solutions of chrome (concentrations ranging from 10 to $150 \mathrm{mg} / \mathrm{L}$ ). The quantity of the adsorbed $\mathrm{Cr}$ (III) and $\mathrm{Cr}(\mathrm{VI})$ was calculated using the following equation:

$$
q_{e}=\frac{\left(C_{o}-C_{e}\right) V}{m}
$$

where $q_{e}$ is the amount of solute adsorbed in the adsorbent $(\mathrm{mg} / \mathrm{g}), C_{o}$ is the initial concentration of the solute $(\mathrm{mg} / \mathrm{L})$, $\mathrm{C}_{e}$ is the equilibrium concentration of the solute $(\mathrm{mg} / \mathrm{L}), \mathrm{V}$ is the solution volume $(\mathrm{L})$, and $m$ is the mass of the adsorbent (g).

\section{Results and Discussion}

3.1. Mineralogical Characterization of the Clay. The X-ray diffraction pattern of bulk clay random powder (not oriented aggregate) is shown in Figure 2. The main reflection was at $15.88 \AA$, which is a typical signal of smectites. The 060 reflection at $1.50 \AA$ confirms that the clay was a dioctahedral smectite, based on this signal in the interval $1.492 \AA$ to 1.504 $\AA$, typical of montmorillonite [36, 48].

Armero-Guayabal clay has a considerable presence of quartz (peaks around 4.29 $\AA, 3.37 \AA$, $2.13 \AA, 1.54 \AA$, and 1.37 $\AA$ ) [49]. Felspars and sillimanite are in the sample too. For the first one, peaks were in $3.76,3.20$, and $3.02 \AA[49,50]$, whereas sillimanite showed one signal at $4.51 \AA$ [49]. The sample also

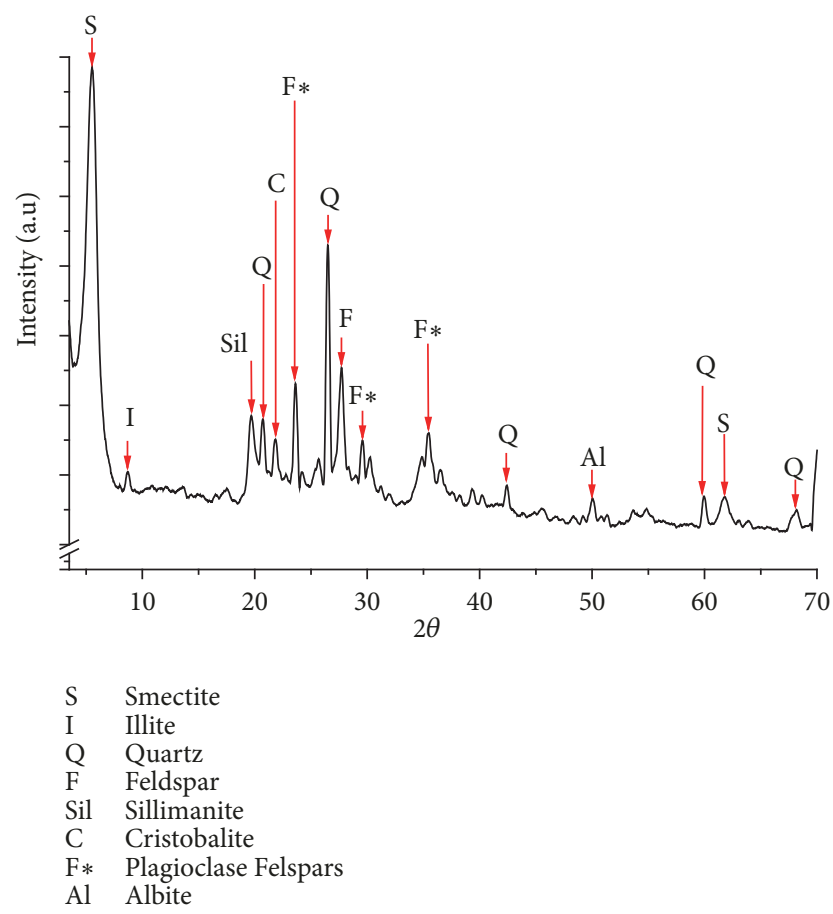

Figure 2: Powder X-ray diffractogram of the Armero-Guayabal clay.

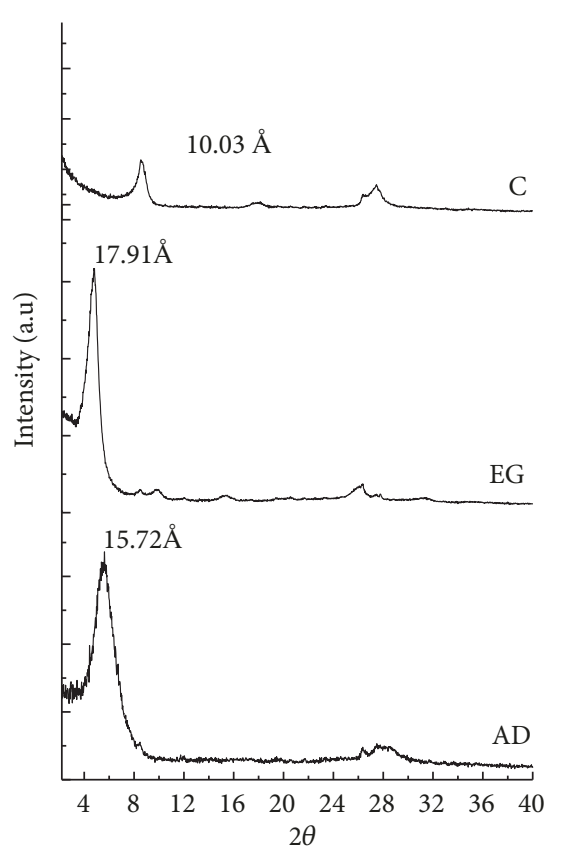

FIGURE 3: XRD pattern the clay fraction $<2 \mu \mathrm{m}$ (oriented mounts): AD: air dried; EG: saturated with ethylene glycol vapor; C: calcined at $500^{\circ} \mathrm{C}$.

had contents of cristobalite (4.08 $\AA$ ) [51] and illite (10.14 $\AA$ ) [49].

The presence of smectite was confirmed by the ethylene glycol solvation test with shifting peak of 001 from 15.72 to $17.91 \AA$ (Figure 3 ). After calcination of the glycolated sample, the peak 001 shifted to $10.03 \AA$, indicating the clay collapse, 

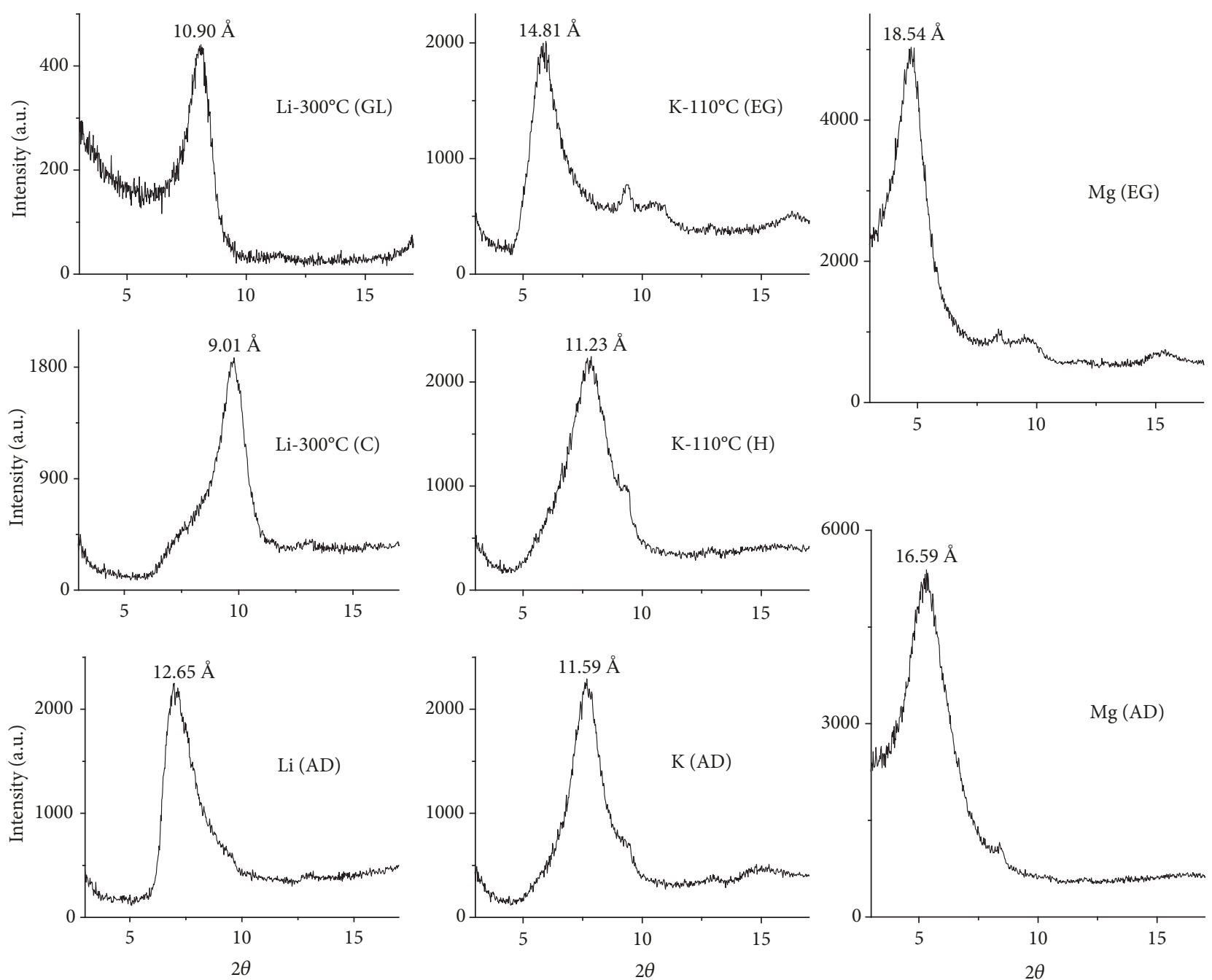

FIGURE 4: XRD pattern the clay fraction $<2 \mu \mathrm{m}$ (oriented mounts) treated with solutions of Li, $\mathrm{K}$, and Mg. AD: air dried; EG: ethylene glycol; GL: glycerol; H: heating; C: calcinated.

typical behavior of a smectite [36]. The XRD patterns for the clay fractions which were saturated with $\mathrm{Li}, \mathrm{K}$ and $\mathrm{Mg}$ solutions are shown in Figure 4.

The sample was tested with lithium for differentiating between montmorillonite and beidellite. The basis of the test was the loss of expansion and cation-exchange properties exhibited by montmorillonite but not by beidellite when it was saturated and heated with lithium. Thus, the irreversible collapse of a smectite mineral to $9.01 \AA$ after Li-saturation and heating at $300^{\circ} \mathrm{C}$ is the criterion for montmorillonite identification, and it is attributed to the neutralization of the negative layer charge by migration of the lithium ions from interlayer positions to vacant octahedral sites $[42,52,53]$.

$\mathrm{K}$-saturated and heated clay at $110^{\circ} \mathrm{C}$ showed a collapse at $11.23 \AA$, and this behavior confirmed that montmorillonite was the main mineral in the sample [36]. The combination of high negative lattice charge and low dehydration energies for $\mathrm{K}^{+}$resulted in the dehydration of potassium within these interlayer spaces and the collapse of the layer to a 10-11 $\AA$ basal spacing [54].
Additionally, ethylene glycol solvation shifted the 001 peak of Mg-saturated smectite to 17-18 $\AA$, whereas the vermiculite 001 peak remained unchanged at 14-15 $\AA$ [55].

The semiquantitative estimation of bulk clay mineralogical composition showed that the most abundant mineral was smectite, with $48 \mathrm{wt} \%$, followed by quartz (21\%), plagioclase (11\%), feldspar (9\%), sillimanite (7\%), illite, cristobalite, and albite (4\%).

3.2. Physicochemical Characterization of the Clay. The chemical compositions of the bulk clay and fraction clay are given in Table 2. The main oxides are $\mathrm{SiO}_{2}, \mathrm{Al}_{2} \mathrm{O}_{3}, \mathrm{Fe}_{2} \mathrm{O}_{3}, \mathrm{CaO}$, and $\mathrm{MgO}$. The major oxides found in clay minerals are $\mathrm{SiO}_{2}$ and $\mathrm{Al}_{2} \mathrm{O}_{3}$. The $\mathrm{SiO}_{2} / \mathrm{Al}_{2} \mathrm{O}_{3}$ ratio has been accepted as a parameter for oxide composition of clays in order to differentiate the type of clay minerals. A recent study proposes the use of a practical chart to identify the predominant clay mineral based on oxide composition in clay soils. The average $\mathrm{SiO}_{2} / \mathrm{Al}_{2} \mathrm{O}_{3}$ ratio for 40 montmorillonite samples evaluated was 2.85 [56]. 
TABLE 2: Chemical composition of the bulk and purified clay used in this study compared with literature data and previous studies.

\begin{tabular}{lcccc}
\hline Compound & & & Chemical Composition (wt\%) \\
Mulk clay & Purified clay & Montmorillonites* [56] & Smectites** [22] \\
\hline $\mathrm{SiO}_{2}$ & 56.58 & 53.70 & 57.68 & 57.84 \\
$\mathrm{Al}_{2} \mathrm{O}_{3}$ & 15.88 & 16.79 & 20.22 & 16.93 \\
$\mathrm{Fe}_{2} \mathrm{O}_{3}$ & 7.51 & 8.33 & 3.17 & 5.84 \\
$\mathrm{CaO}$ & 3.43 & 2.50 & 1.20 & 1.46 \\
$\mathrm{MgO}$ & 2.24 & 2.46 & 4.22 & 1.51 \\
$\mathrm{~K}_{2} \mathrm{O}$ & 1.73 & 1.45 & 0.44 & 1.36 \\
$\mathrm{Na}_{2} \mathrm{O}$ & 1.11 & 2.22 & 0.98 & 0.94 \\
$\mathrm{TiO}_{2}$ & 0.70 & 0.68 & 0.24 & 0.52 \\
$\mathrm{MnO}$ & 0.13 & 0.11 & 1.74 & 0.06 \\
\hline
\end{tabular}

*: average of 40 montmorillonite samples [56].

$* *$ : average of 32 smectite samples located in the north of Tolima [22].

In this study, the $\mathrm{SiO}_{2} / \mathrm{Al}_{2} \mathrm{O}_{3}$ ratio was 3.43 , which is higher than that reported by Sivrikaya et al. [56]. However, it is within the range found for the smectites from north of Tolima (2.70 to 3.93) [23] and three Brazilian smectites (3.14 to 4.09) [57]. Clay from Armero-Guayabal presented a reddish color, which can be associated with the high content of $\mathrm{Fe}_{2} \mathrm{O}_{3}$. The total organic carbon content for bulk and purified clay was 45.30 and $42.17 \mathrm{mg}$ of $\mathrm{C} / \mathrm{kg}$, respectively, very low values suggesting a minimum amount of organic matter in the samples.

In accordance with the chemical composition of $\mathrm{SiO}_{2}$ (56.58 and $53.70 \mathrm{wt} \%$ ), $\mathrm{Al}_{2} \mathrm{O}_{3}+\mathrm{Fe}_{2} \mathrm{O}_{3}$, (23.39 and $25.12 \mathrm{wt} \%$ ), and $\mathrm{MgO}+\mathrm{CaO}+\mathrm{Na}_{2} \mathrm{O}+\mathrm{K}_{2} \mathrm{O}$ (8.51 and $8.63 \mathrm{wt} \%$ ), the bulk and purified clay samples were located in the montmorillonite zone of the reported diagrams by Sivikaya et al. [56].

After the purification process the chemical composition of the bulk clay changed due to the presence of clay minerals like quartz, feldspar, sillimanite, plagioclase, and cristobalite which were removed from the sample (Figure 3), meaning changes in the chemical composition as shown in Table 2. It shows that the main exchangeable cations are $\mathrm{Ca}^{2+}, \mathrm{Mg}^{2+}$, $\mathrm{K}^{+}$, and $\mathrm{Na}^{+}$. The percentage of sodium increased whereas calcium, magnesium, and potassium percentage decreased for the purified clay regarding the bulk clay. Due to the purification process, sodium hexametaphosphate $\left(\mathrm{NaPO}_{3}\right)_{6}$ (Section 2.2) was used, causing the exchangeable cations to be exchanged by sodium cations.

The cation exchange capacity (CEC) can be defined as the sum of all the cations that a mineral can associate with a certain $\mathrm{pH}$. It has two origins: one is the isomorphic substitution in the tetrahedral and/or octahedral sheet of the clay mineral layer and the other is the dissociation of aluminum groups on the edges [58]. The CEC of the bulk clay and clay fraction were of 39.08 and $43.02 \mathrm{meq} / 100 \mathrm{~g}$, values slightly lower than those reported for montmorillonites from the Valle del Cauca-Colombia (46.4 and $53.0 \mathrm{meq} / 100 \mathrm{~g}$ ) $[15,17]$ and for smectite-type clays (range within 80-150 $\mathrm{meq} / 100 \mathrm{~g})[59,60]$.

The Foster swelling of the original sample (bulk clay) was estimated in $7 \mathrm{~mL} / 2 \mathrm{~g}$ and $31 \mathrm{~mL} / 2 \mathrm{~g}$ to the exchanged clay
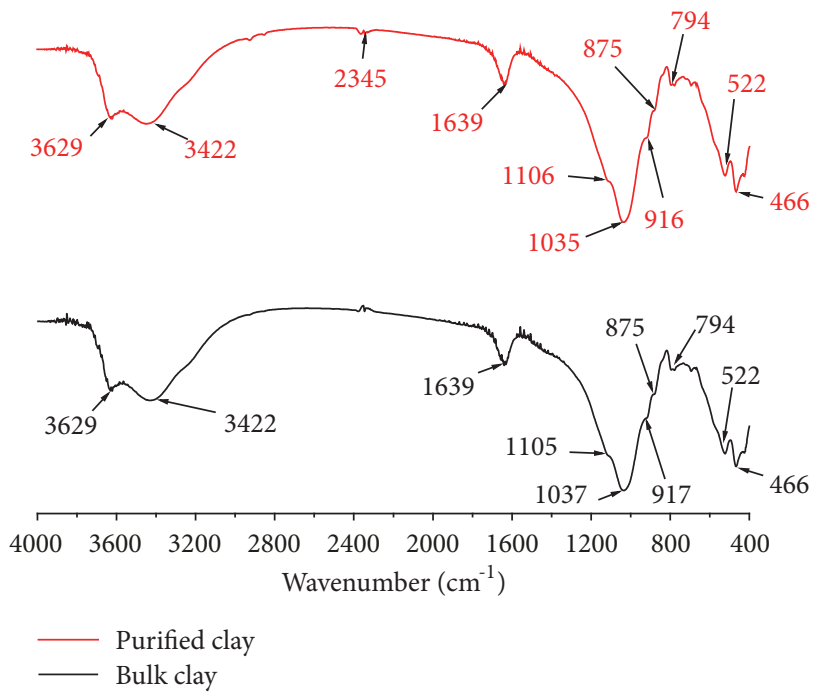

FIGURE 5: FT-IR spectra of the bulk and purified clay.

by sodium. According to Table 2 the bulk clay is a calcium and magnesium bentonite, and it is well known that this clay shows no swelling on hydration like the sodium bentonite [61]; for that reason the exchanged clay by sodium has a Foster swelling higher than the bulk clay sample.

The FT-IR spectrum of the bulk and purified clay (Figure 5) shows the presence of $\mathrm{Al}-\mathrm{OH}$ as stretching bands at $3629 \mathrm{~cm}^{-1}$ and as bending bands at $916-917 \mathrm{~cm}^{-1}$. The large band near $1035-1037 \mathrm{~cm}^{-1}$ corresponds to $\mathrm{Si}-\mathrm{O}$ stretching vibration. The above signals can be considered as characteristic of a dioctahedral clay and, more precisely, a dioctahedral smectite $[62,63]$. Montmorillonites contain both a tetrahedral and octahedral isomorphous substitution, $\mathrm{Al}$ (and occasionally $\mathrm{Fe}^{3+}$ ) for $\mathrm{Si}$ in the former case, and $\mathrm{Fe}^{3+}$ and $\mathrm{Mg}$ for $\mathrm{Al}$ in the latter. As a result of these substitutions, the crystalline order is reduced and structural imperfections arise. High-iron montmorillonites show a typical broad $\mathrm{OH}-$ stretching band at $3627 \mathrm{~cm}^{-1}$, while those with low-iron content present it at $3622 \mathrm{~cm}^{-1}$ [64]. 


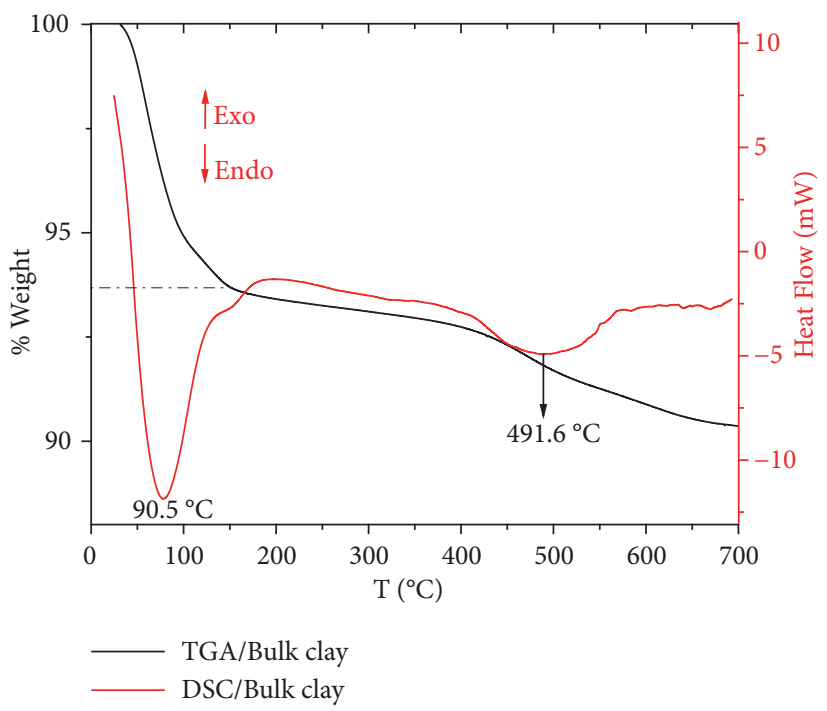

(a)

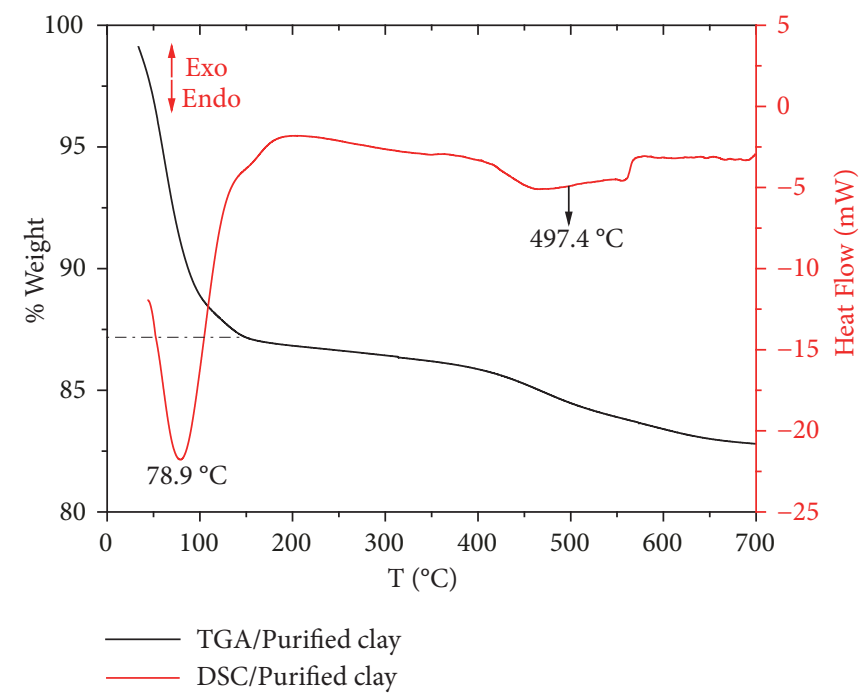

(b)

Figure 6: TGA/DSC curves: (a) bulk clay and (b) purified clay.

The broad band centered near $3422 \mathrm{~cm}^{-1}$ is due to the $-\mathrm{OH}$ stretching mode of the interlayer water. The overlaid absorption peak in the region of $1639 \mathrm{~cm}^{-1}$ is assigned to the -OH bending mode of adsorbed water [65]. The band in the region of $875 \mathrm{~cm}^{-1}$ is due to the Si-O-Al stretching mode for montmorillonite $[65,66]$. The weak band at $794 \mathrm{~cm}^{-1}$ corresponds to $\mathrm{Si}-\mathrm{O}$ stretching vibration of quartz [62]. The bands at $522 \mathrm{~cm}^{-1}$ and $466 \mathrm{~cm}^{-1}$ are assigned to the $\mathrm{Si}-\mathrm{O}-\mathrm{Al}$ and $\mathrm{Si}-\mathrm{O}-\mathrm{Si}$ bending vibration, respectively [6567].

The thermogravimetric analysis (TGA) and the differential scanning calorimetry (DSC) are considered simple and accurate methods to evaluate the thermal stability and changes in the mineral under the heating process. The TGA/DSC curves for bulk and purified clays are shown in Figure 6. The first thermal step, corresponding to a reduction in mass at temperatures below $150^{\circ} \mathrm{C}$, can be associated with the loss of physisorbed water molecules $[68,69]$ (endothermic peak centered at 90.5 and $78.5^{\circ} \mathrm{C}$, respectively). This value is approximately $6.4 \%$ of the weight for bulk clay, while in a purified clay sample, it reaches up to $12.8 \%$. In the second step, mass loss occurred due to dehydroxylation of clay (endothermic peak centered at 491.6 and $497.4^{\circ} \mathrm{C}$, respectively), consistent with montmorillonites literature report [69]. The total mass loss of the bulk clay and clay fraction samples was $9.7 \%$ and $17.2 \%$. Bulk clay showed the lowest mass loss because this material contains impurities such as quartz, which cannot physisorb water in its structure.

The bulk and clay purified isotherms are shown in Figure 7. They were classified as a type IVa and their hysteresis loops are H3. The initial part of isotherm $\left(\mathrm{p} / \mathrm{p}^{\circ}<0.41\right)$, corresponding to the monolayer region, could be ascribed to physique adsorption at the surface of the clay. There are two distinctive features of the type $\mathrm{H} 3$ loop: (i) the adsorption

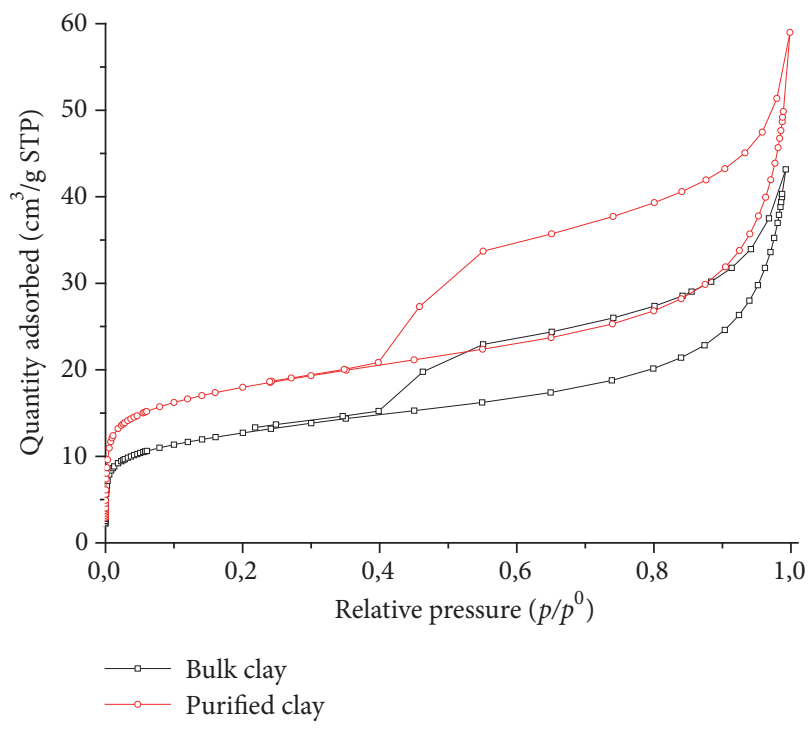

FIGURE 7: $\mathrm{N}_{2}$ physisorption isotherm of the bulk and purified clay.

branch resembles a type II isotherm and (ii) the lower limit of the desorption branch is normally located at the cavitationinduced $\mathrm{p} / \mathrm{p}^{0}$. The loop of this type is given by nonrigid aggregates of plate-like particles [46].

The specific surface area was $45.1 \mathrm{~m}^{2} / \mathrm{g}$ and $62.9 \mathrm{~m}^{2} / \mathrm{g}$ for bulk and purified clay, respectively. The pore volume at $p / p^{\circ}=0.99$ is of $0.0654 \mathrm{~cm}^{3} / \mathrm{g}$ for bulk material and $0.0853 \mathrm{~cm}^{3} / \mathrm{g}$ for purified clay. The $t$ plot method was used to determine the specific area and the volume developed by micropores of the samples. These values are $8.7 \mathrm{~m}^{2} / \mathrm{g}$ and $0.0031 \mathrm{~cm}^{3} / \mathrm{g}$ for bulk clay and $16.5 \mathrm{~m}^{2} / \mathrm{g}$ and $0.0058 \mathrm{~cm}^{3} / \mathrm{g}$ for clay fraction, respectively. The specific surface area of 


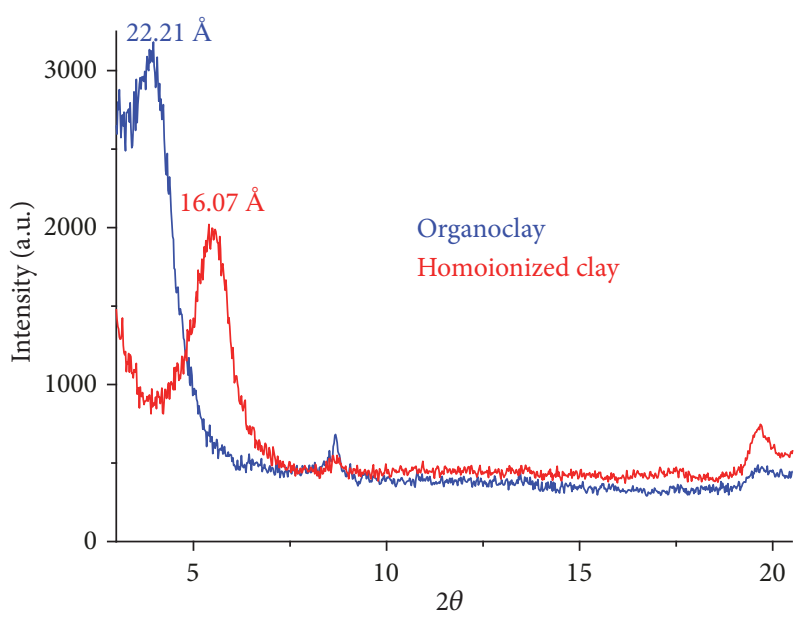

FIGURE 8: XRD of homoionized clay and organoclay.

these materials is fundamentally the external surface, characteristic of a structure of closed sheets, attributed to the heterogeneous arrangement of the aluminosilicate sheets [1].

3.3. XRD of Organoclay. The shift of the $\mathrm{d}_{001}$ signal from 16.02 $\AA$, for the homoionized clay, to $22.21 \AA$, for the organoclay (see Figure 8), is associated with the incorporation of the HDTMA cation in a pseudo-trilayer/paraffinic arrangement $\left(\mathrm{d}_{001}>22.0 \AA\right.$, aliphatic chains oblique to the basal surface $)$ [70]. Variation between the basal spacing $\mathrm{d}_{001}$ and the concentration of the surfactant has been found [71, 72]. Upon increasing the surfactant loading (HDTMA-Br), the interlayer spacing of organoclays gradually increased. There is a lateral monolayer arrangement in $0.25 \mathrm{CEC}$ and $0.5 \mathrm{CEC}$. The basal spacing at $18.2 \AA$ with a shoulder of $22.0 \AA$ indicates a lateral bilayer arrangement and the $\mathrm{d}_{001}$ spacing of $22.0 \AA$ at 2.0 CEC suggests a pseudotrimolecular layer arrangement [72].

3.4. Preliminary Tests of Chromium Adsorption. Homoionized clay and organoclay samples were used to evaluate the effect of $\mathrm{pH}$ on the adsorption of $\mathrm{Cr}(\mathrm{III})$ and $\mathrm{Cr}(\mathrm{VI})$ ions from an aqueous solution (see Figure 9). The homoionized clay removed trivalent chromium by exchanging the $\mathrm{Na}^{+}$ compensation ions by $\mathrm{Cr}^{3+}$ ions. The organoclay removed hexavalent chromium by means of an anionic exchange mechanism of the counter-ion bromide present in the molecule of HDTMA-Br having been exchanged by ions $\mathrm{Cr}_{2} \mathrm{O}_{7}{ }^{2-}$ and $\mathrm{HCrO}_{4}{ }^{-}$[73]. The organic surfactant was fixed to the interlayer of bentonite by van der Waals hydrophobic interactions [30].

At $\mathrm{pH} 3$ and 4, homoionized clay achieved a $\mathrm{Cr}$ (III) removal greater than $85.05 \pm 2.04 \%$, while organoclay had the highest removal $(44.09 \pm 1.62 \%)$ at $\mathrm{pH} 4$. No tests were performed at $\mathrm{pH}$ values greater than 4.8 because removal of $\mathrm{Cr}(\mathrm{III})$ was promoted by precipitation and not by cation exchange with clay [73]. Removals of $\mathrm{Cr}(\mathrm{VI})$ greater than $82.93 \pm 1.03 \%$ were obtained with the organoclay at $\mathrm{pH}$ between 3 and 5, while homoionized clay achieved a removal of $32.69 \pm 1.89 \%$ at $\mathrm{pH} 6$.

In Figure 10, the adsorption isotherms of $\mathrm{Cr}$ (III) and $\mathrm{Cr}(\mathrm{VI})$ are presented. Data of isotherms $\left(q_{e}\right.$ vs $\left.C_{e}\right)$ were adjusted to the Langmuir model by means of a nonlinear regression analysis. In both cases, the adjustment of data had an $\mathrm{R}^{2}$ of 0.98 .

The maximum adsorption capacity of $\mathrm{Cr}(\mathrm{III})$ in homoionized clay was $5.37 \mathrm{mg} / \mathrm{g}$, value slightly higher than that obtained with a bentonite from Gaomiaozi, China $(4.68 \mathrm{mg} / \mathrm{g})$ [74]. For $\mathrm{Cr}(\mathrm{VI})$, a maximum adsorption capacity of $9.65 \mathrm{mg} / \mathrm{g}$ was obtained, a value higher than that obtained for this metal at $\mathrm{pH} 4$ in an organobentonite $(8.08 \mathrm{mg} / \mathrm{g})$ [75]. When activated carbon is used as an adsorbent for the removal of $\mathrm{Cr}(\mathrm{III})$ and $\mathrm{Cr}(\mathrm{VI}), \mathrm{Q}_{o}$ values of $2.33\left(\mathrm{pH} 4,25^{\circ} \mathrm{C}\right)$ [76] and $15.07 \mathrm{mg} / \mathrm{g}\left(\mathrm{pH} 5.38,20^{\circ} \mathrm{C}\right)$ [77], respectively, have been reported.

\section{Conclusions}

The bulk clay of Armero-Guayabal is composed mainly of $\mathrm{SiO}_{2}, \mathrm{Al}_{2} \mathrm{O}_{3}$, and $\mathrm{Fe}_{2} \mathrm{O}_{3}$, in a proportion of $56.58,15.88$, and $7.51 \mathrm{wt} \%$, respectively. These values are in the range established for montmorillonites, which is the main mineral component of bentonites. The mineralogical composition of the bulk clay showed that the most abundant mineral is smectite (48 wt\%). The introduction of hexadecyltrimethylammonium cations $\left(\mathrm{HDTMA}^{+}\right)$in the interlaminar spacing of the homoionized clay produced an increase in the basal spacing $\left(\mathrm{d}_{001}\right)$ of the clay, going from 16.70 to $22.21 \AA$. This result demonstrates the modification potential of bentonite-type clay due to its high cation exchange capacity. Homoionized clay and organoclay achieved $\mathrm{Cr}$ (III) and $\mathrm{Cr}$ (VI) removals greater than $85.05 \pm 2.04 \%$ (pH between 3 and 4 ) and $82.93 \pm$ $1.03 \%$ (pH between 3 and 5), respectively, demonstrating the potential of these materials as adsorbents for the removal of heavy metals in an aqueous solution. This work was intended to become useful for future studies related to the use of this Colombian clay type bentonite for industrial purposes as an adsorbent or as a substrate to obtain nanostructured materials.

\section{Data Availability}

All the data were included in the article through figures and tables.

\section{Conflicts of Interest}

The authors declare that there are no conflicts of interest regarding the publication of this paper.

\section{Acknowledgments}

We gratefully acknowledge the financial support of Universidad Nacional de Colombia Sede Manizales through the projects DIMA-UNAL [Codes 38621 and 38719]. 


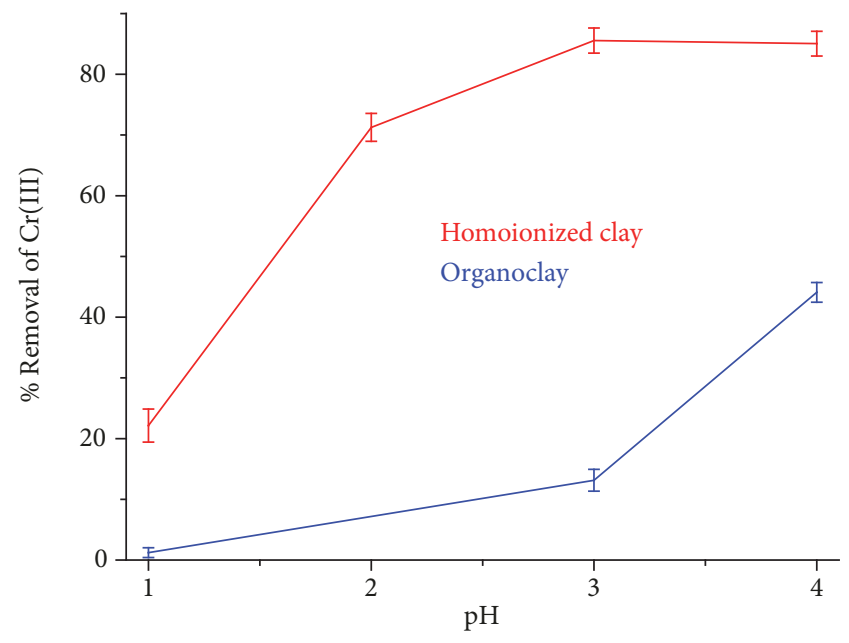

(a)

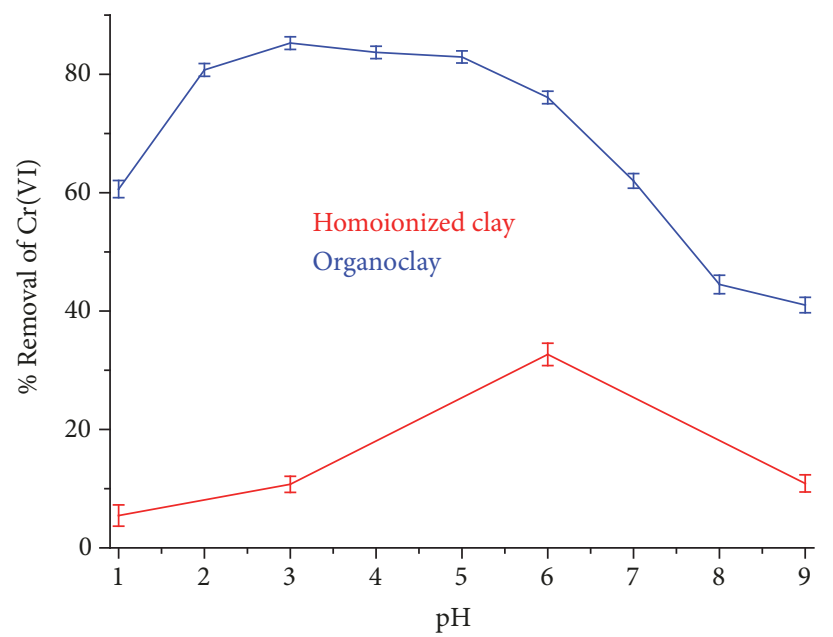

(b)

Figure 9: Adsorption of (a) $\mathrm{Cr}$ (III) and (b) $\mathrm{Cr}(\mathrm{VI})$ on homoionized clay and organoclay. The error bars represent the standard deviation of measurements of $\mathrm{Cr}$ in three adsorption tests.

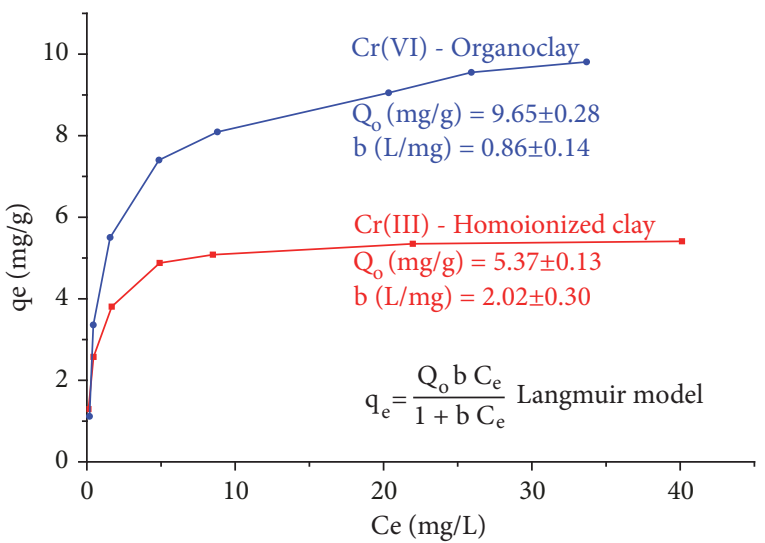

Figure 10: Adsorption isotherms of $\mathrm{Cr}(\mathrm{III})$ and $\mathrm{Cr}(\mathrm{VI})$ at $20^{\circ} \mathrm{C}$ and $\mathrm{V}=50 \mathrm{~mL}$ in homoionized clay ( $\mathrm{pH} 3.5,0.96 \mathrm{~g}$ adsorbent) and organoclay ( $\mathrm{pH} 3.4,0.44 \mathrm{~g}$ adsorbent).

\section{References}

[1] F. Bergaya and G. Lagaly, "Chapter 1. General introduction: clays, clay minerals, and clay science," in Handbook of Clay Science, vol. 1 of Developments in Clay Science, pp. 1-18, Elsevier, Oxford, UK, 2006.

[2] M. Brigatti, E. Galán, and B. Theng, "Chapter 2. Structure and mineralogy of clay minerals," in Handbook of Clay Science, vol. 1 of Developments in Clay Science, pp. 19-86, Elsevier, Oxford, UK, 2006.

[3] C. B. Molina, J. A. Casas, A. H. Pizarro, and J. J. Rodríguez, "Chapter 16. Pillared clays as green chemistry catalysts: Application to wastewater treatment," in Clay: Types, Properties and Uses, J. P. Humphrey and D. E. Boyd, Eds., pp. 435-474, Nova Science Publishers, Hauppauge, NY, USA, 2011.

[4] C. D. Barton and A. D. Karathanasis, "Clay minerals," in Encyclopedia of Soil Science, R. Lal, Ed., CRC Press, New York, NY, USA, 2002.
[5] C. I. R. De Oliveira, M. C. G. Rocha, A. L. N. Da Silva, and L. C. Bertolino, "Characterization of bentonite clays from Cubati, Paraíba Northeast of Brazil," Ceramica, vol. 62, no. 363, pp. 272277, 2016

[6] N. Stankovic, M. Logar, J. Lukovic et al., "Characterization of bentonite clay from 'Greda' deposit," Processing and Application of Ceramics, vol. 5, no. 2, pp. 97-101, 2011.

[7] N. H. Darton, Geology Bighorn Mountains, U.S. Geological Survey, Washington, DC, USA, 1906.

[8] N. Jaeckels, S. Tenzer, M. Meier et al., "Influence of bentonite fining on protein composition in wine," LWT-Food Science and Technology, vol. 75, pp. 335-343, 2017.

[9] H. Koyuncu, A. R. Kul, A. Çalimli, N. Yildiz, and H. Ceylan, "Adsorption of dark compounds with bentonites in apple juice," LWT- Food Science and Technology, vol. 40, no. 3, pp. 489-497, 2007.

[10] N. Granizo, J. M. Vega, D. De La Fuente, J. Simancas, and M. Morcillo, "Ion-exchange pigments in primer paints for anticorrosive protection of steel in atmospheric service: Cationexchange pigments," Progress in Organic Coatings, vol. 75, no. 3, pp. 147-161, 2012.

[11] J. Cervini-Silva, Antonio-Nieto-Camacho, S. Kaufhold, K. Ufer, and E. R. de Jesús, "The anti-inflammatory activity of bentonites," Applied Clay Science, vol. 118, pp. 56-60, 2015.

[12] J. Nones, H. G. Riella, A. G. Trentin, and J. Nones, "Effects of bentonite on different cell types: A brief review," Applied Clay Science, vol. 105-106, pp. 225-230, 2015.

[13] S. S. Al-Shahrani, "Treatment of wastewater contaminated with cobalt using Saudi activated bentonite," Alexandria Engineering Journal, vol. 53, no. 1, pp. 205-211, 2014.

[14] D. Copetti, K. Finsterle, L. Marziali et al., "Eutrophication management in surface waters using lanthanum modified bentonite: A review," Water Research, vol. 97, pp. 162-174, 2015.

[15] J. G. Carriazo, E. Guelou, J. Barrault, J. M. Tatibouët, and S. Moreno, "Catalytic wet peroxide oxidation of phenol over Al$\mathrm{Cu}$ or Al-Fe modified clays," Applied Clay Science, vol. 22, no. 6, pp. 303-308, 2003. 
[16] A. De Stefanis and A. A. G. Tomlinson, "Towards designing pillared clays for catalysis," Catalysis Today, vol. 114, no. 2-3, pp. 126-141, 2006.

[17] N. R. Sanabria, M. A. Centeno, R. Molina, and S. Moreno, "Pillared clays with $\mathrm{Al}-\mathrm{Fe}$ and $\mathrm{Al}-\mathrm{Ce}-\mathrm{Fe}$ in concentrated medium: Synthesis and catalytic activity," Applied Catalysis A: General, vol. 356, no. 2, pp. 243-249, 2009.

[18] T. J. Brown, N. E. Idoine, E. R. Raycraft et al., "World Mineral Production 2008-2012," in British Geological Survey Nottingham, UK, 2014.

[19] T. J. Brown, C. E. Wrighton, N. E. Idoine et al., "World Mineral Production 2010-2014," in British Geological Survey, Nottingham, UK, 2016.

[20] T. J. Brown, C. E. Wrighton, E. R. Raycraft et al., "World Mineral Production 2009-2013," in British Geological Survey, Nottingham, UK, 2015.

[21] O. H. Laguna, Efecto del contenido esmectítico en procesos de pilarización de minerales arcillosos proveniente de la cordillera central de Colombia, Tesis, Universidad Nacional de Colombia, Bogotá DC, Colombia, 2007.

[22] J. A. Camacho-Gómez and C. M. Celada-Arango, Definición de zonas potenciales para esmectitas en los departamentos del Valle del Cauca, Tolima y Caldas, Instituto Colombiano de Geologia y Minería - Ingeominas, Ministerio de Minas y Energía, Bogotá, Colombia, 2004.

[23] O. H. Laguna, E. C. M. Molina G, S. Moreno, and R. Molina G, "Naturaleza mineralógica de esmectitas provenientes de la formación Honda (noreste del Tolima - Colombia)," Boletín de Ciencias de la Tierra, vol. 23, pp. 55-68, 2008.

[24] J. G. Carriazo, M. A. Centeno, J. A. Odriozola, S. Moreno, and R. Molina, "Effect of Fe and Ce on Al-pillared bentonite and their performance in catalytic oxidation reactions," Applied Catalysis A: General, vol. 317, no. 1, pp. 120-128, 2007.

[25] L. A. Galeano, A. Gil, and M. A. Vicente, "Effect of the atomic active metal ratio in $\mathrm{Al} / \mathrm{Fe}-, \mathrm{Al} / \mathrm{Cu}$ - and $\mathrm{Al} /(\mathrm{Fe}-\mathrm{Cu})$ intercalating solutions on the physicochemical properties and catalytic activity of pillared clays in the CWPO of methyl orange," Applied Catalysis B: Environmental, vol. 100, no. 1-2, pp. 271-281, 2010.

[26] A. Pérez, M. A. Centeno, J. A. Odriozola, R. Molina, and S. Moreno, "The effect of ultrasound in the synthesis of clays used as catalysts in oxidation reactions," Catalysis Today, vol. 133-135, no. 1-4, pp. 526-529, 2008.

[27] N. R. Sanabria, P. Ávila, M. Yates, S. B. Rasmussen, R. Molina, and S. Moreno, "Mechanical and textural properties of extruded materials manufactured with AlFe and AlCeFe pillared bentonites," Applied Clay Science, vol. 47, no. 3-4, pp. 283-289, 2010.

[28] L. Aloui, F. Ayari, A. Ben Othman, and M. Trabelsi-Ayadi, "Heavy metals removal from watercourses by low cost natural Tunisian material environmental protection," International Journal of Engineering and Applied Sciences, vol. 2, no. 7, 2015.

[29] T. De Oliveira, R. Guégan, T. Thiebault et al., "Adsorption of diclofenac onto organoclays: Effects of surfactant and environmental ( $\mathrm{pH}$ and temperature) conditions," Journal of Hazardous Materials, vol. 323, pp. 558-566, 2017.

[30] H. He, L. Ma, J. Zhu, R. L. Frost, B. K. G. Theng, and F. Bergaya, "Synthesis of organoclays: A critical review and some unresolved issues," Applied Clay Science, vol. 100, no. C, pp. 2228, 2014.

[31] Y.-C. Lee, W.-K. Park, and J.-W. Yang, "Removal of anionic metals by amino-organoclay for water treatment," Journal of Hazardous Materials, vol. 190, no. 1-3, pp. 652-658, 2011.
[32] Hidrología Geología Ambiental, Muestreo geoquímico de sedimentos activos o de lecho seco grupo II - Bloque 137, Instituto Colombiano de Geologia y Minería - Ingeominas, Ministerio de Minas y Energía, Bogotá, Colombia, 2014.

[33] P. R. Day, "Particle fractionation and particle-size analysis," in Methods of Soil Analysis, Part 1. Physical and Mineralogical Methods, C. A. Black, D. D. Evans, L. E. Ensminger, J. L. White, and F. E. Clarck, Eds., pp. 545-567, American Society of Agronomy, Inc., Madison, Wis, USA, 1965.

[34] D. L. Bish and R. C. J. Reynolds, "Chapter 4. Sample preparation for X-ray diffraction," in Reviews in Mineralogy, D. L. Bish and R. C. J. Post, Eds., vol. 20 of Modern Powder Diffraction, pp. 7399, Mineralogical Society of America, Washington, Wash, USA, 1989.

[35] Z. Gong, L. Liao, G. Lv, and X. Wang, "A simple method for physical purification of bentonite," Applied Clay Science, vol. 119, pp. 294-300, 2016.

[36] J. Thorez, Practical Identification of Clay Minerals: A Handbook for Teachers and Students in Clay Mineralogy, Clay. Mineralogy and G. Lelotte, Eds., Belgium, 1976.

[37] L. G. Schultz, "Quantitative interpretation of mineralogical composition from X-ray and chemical data for the Pierre Shale," U.S. Geological Survey professional paper, 1964.

[38] X. Zhou, D. Liu, H. Bu et al., "XRD-based quantitative analysis of clay minerals using reference intensity ratios, mineral intensity factors, Rietveld, and full pattern summation methods: A critical review," Solid Earth Sciences, vol. 3, no. 1, pp. 16-29, 2018.

[39] V. Martins, J. Dubert, J.-M. Jouanneau et al., "A multiproxy approach of the Holocene evolution of shelf-slope circulation on the NW Iberian Continental Shelf," Marine Geology, vol. 239, no. 1-2, pp. 1-18, 2007.

[40] I. Abrantes and F. Rocha, "Sedimentary dynamics of the Aveiro Shelf (Portugal)," Journal of Coastal Research, no. 50, pp. 10051009, 2007.

[41] P. E. Biscaye, "Mineralogy and sedimentation of recent deep-sea clay in the Atlantic ocean and adjacent seas and oceans," Bulletin of the Geological Society of America, vol. 76, no. 7, pp. 803-832, 1965.

[42] O. Karnland, S. Olsson, and U. Nilsson, "Mineralogy and sealing properties of various bentonites and smectite-rich clay materials," Technical Report TR-06-30, Stockholm, Sweden, 2006.

[43] ICONTEC, NTC 2271, Instituto Colombiano de Normas Técnicas, Bogotá, Colombia, 1987.

[44] H. Chapman, "Cation-Exchange Capacity," in Methods of Soil Analysis, Part 2. Chemical and Microbiological Properties, C. A. Black, D. D. Evans, L. E. Ensminger, J. L. White, and F. E. Clarck, Eds., pp. 891-901, American Society of Agronomy, Inc., Madison, Wis, USA, 1965.

[45] S. J. Gregg and K. S. W. Sing, Adsorption, Surface Area and Porosity, Academic Press, London, UK, 1982.

[46] M. Thommes, K. Kaneko, A. V. Neimark et al., "Physisorption of gases, with special reference to the evaluation of surface area and pore size distribution (IUPAC Technical Report)," Pure and Applied Chemistry, vol. 87, no. 9-10, pp. 1051-1069, 2015.

[47] B. Erdem, A. S. Özcan, and A. Özcan, "Preparation of HDTMAbentonite: Characterization studies and its adsorption behavior toward dibenzofuran," Surface and Interface Analysis, vol. 42, no. 6-7, pp. 1351-1356, 2010.

[48] D. M. Moore and R. C. Reynolds Jr, X-Ray Diffraction and Identification and Analysis of Clay Minerals, Oxford University Press, Oxford, UK, 1997. 
[49] W. F. Bradley, G. W. Brindley, G. Brown et al., The X-Ray Identification and Crystal Structures of Clay Minerals, Mineralogical Society, London, UK, 1961.

[50] D. Tsozué, A. N. Nzeugang, J. R. Mache, S. Loweh, and N. Fagel, "Mineralogical, physico-chemical and technological characterization of clays from Maroua (Far-North, Cameroon) for use in ceramic bricks production," Journal of Building Engineering, vol. 11, pp. 17-24, 2017.

[51] S. Mahmoudi, A. Bennour, E. Srasra, and F. Zargouni, "Characterization, firing behavior and ceramic application of clays from the Gabes region in South Tunisia," Applied Clay Science, vol. 135, pp. 215-225, 2017.

[52] C. H. Lim and M. L. Jackson, "Expandable phyllosilicate reactions with lithium on heating.," Clays and Clay Minerals, vol. 34, no. 3, pp. 346-352, 1986.

[53] E. Srasra, F. Bergaya, and J. J. Fripiat, "Infrared spectroscopy study of tetrahedral and octahedral substitutions in an interstratified illite-smectite clay," Clays and Clay Minerals, vol. 42, no. 3, pp. 237-241, 1994.

[54] J. J. Howard, "Lithium and potassium saturation of illite/ smectite clays from interlaminated shales and sandstones.," Clays and Clay Minerals, vol. 29, no. 2, pp. 136-142, 1981.

[55] L. Carison, "Working Report 2004-02. Bentonite mineralogy. Part 1: Methods of investigation - a literature review, Part 2: mineralogical research of selected bentonites," Geological Survey of Finland, Olkiluoto, Finland, 2004.

[56] O. Sivrikaya, B. Uzal, and Y. E. Ozturk, "Practical charts to identify the predominant clay mineral based on oxide composition of clayey soils," Applied Clay Science, vol. 135, pp. 532-537, 2017.

[57] L. C. A. Silva, E. A. Silva, M. R. Monteiro, C. Silva, J. G. Teleken, and H. J. Alves, "Effect of the chemical composition of smectites used in KF/Clay catalysts on soybean oil transesterification into methyl esters," Applied Clay Science, vol. 102, pp. 121-127, 2014.

[58] G. Lagaly, "Characterization of clays by organic compounds.," Clay Minerals, vol. 16, no. 1, pp. 1-21, 1981.

[59] R. E. Grim, Clay Mineralogy, McGraw-Hill Book Company, Inc., New York, NY, USA, 1968.

[60] I. Y̌lmaz, "Relationships between liquid limit, cation exchange capacity, and swelling potentials of clayey soils," Eurasian Soil Science, vol. 37, no. 5, pp. 506-512, 2004.

[61] M. D. Foster, "The Relation Between Composition and Swelling in Clays ," Clays and Clay Minerals, vol. 3, no. 1, pp. 205-220, 1954.

[62] G. Borchardt, "Montmorillonite and other smectite minerals," in Minerals in Soil Environments, J. B. Dixon and S. B. Weed, Eds., pp. 293-330, Soil Science Society of America, Madison, wis, US, 1977.

[63] P. Djomgoue and D. Njopwouo, "FT-IR Spectroscopy Applied for Surface Clays Characterization," Journal of Surface Engineered Materials and Advanced Technology, vol. 03, no. 04, pp. 275-282, 2013.

[64] M. J. Wilson, Clay Mineralogy: Spectroscopic and Chemical Determinative Methods, Chapman Hall, London, UK, 1994.

[65] B. A. Fil, C. Özmetin, and M. Korkmaz, "Characterization and electrokinetic properties of montmorillonite," Bulgarian Chemical Communications, vol. 46, no. 2, pp. 258-263, 2014.

[66] S. Akyüz, T. Akyüz, and A. E. Yakar, "FT-IR spectroscopic investigation of adsorption of 3-aminopyridine on sepiolite and montmorillonite from Anatolia," Journal of Molecular Structure, vol. 565-566, pp. 487-491, 2001.
[67] H. A. Patel, R. S. Somani, H. C. Bajaj, and R. V. Jasra, "Preparation and characterization of phosphonium montmorillonite with enhanced thermal stability," Applied Clay Science, vol. 35, no. 3-4, pp. 194-200, 2007.

[68] L. A. Galeano, A. Gil, and M. A. Vicente, "Strategies for immobilization of manganese on expanded natural clays: Catalytic activity in the CWPO of methyl orange," Applied Catalysis B: Environmental, vol. 104, no. 3-4, pp. 252-260, 2011.

[69] F. Ayari, E. Srasra, and M. Trabelsi-Ayadi, "Characterization of bentonitic clays and their use as adsorbent," Desalination, vol. 185, no. 1-3, pp. 391-397, 2005.

[70] Q. Zhao, H. Choo, A. Bhatt, S. E. Burns, and B. Bate, "Review of the fundamental geochemical and physical behaviors of organoclays in barrier applications," Applied Clay Science, vol. 142, pp. 2-20, 2017.

[71] Y. Xi, Z. Ding, H. He, and R. L. Frost, "Structure of organoclaysan X-ray diffraction and thermogravimetric analysis study," Journal of Colloid and Interface Science, vol. 277, no. 1, pp. 116-120, 2004.

[72] Y. Park, G. A. Ayoko, E. Horváth, R. Kurdi, J. Kristof, and R. L. Frost, "Structural characterisation and environmental application of organoclays for the removal of phenolic compounds," Journal of Colloid and Interface Science, vol. 393, no. 1, pp. 319334, 2013.

[73] S. A. Khan, Riaz-ur-Rehman, and M. A. Khan, "Adsorption of chromium (III), chromium (VI) and silver (I) on bentonite," Waste Management, vol. 15, no. 4, pp. 271-282, 1995.

[74] Y.-G. Chen, Y. He, W.-M. Ye, C.-H. Lin, X.-F. Zhang, and B. Ye, "Removal of chromium(III) from aqueous solutions by adsorption on bentonite from Gaomiaozi, China," Environmental Earth Sciences, vol. 67, no. 5, pp. 1261-1268, 2012.

[75] R. Ramos, A. Jacobo-Azuara, O. L. Torres-River et al., "Adsorption of chromium (VI) from water solution onto organobentonite," Journal of Environmental Engineering and Management, vol. 18, no. 5, pp. 311-317, 2008.

[76] R. Leyva-Ramos, L. Fuentes-Rubio, R. M. Guerrero-Coronado, and J. Mendoza-Barron, "Adsorption of trivalent chromium from aqueous solutions onto activated carbon," Journal of Chemical Technology and Biotechnology, vol. 62, no. 1, pp. 6467, 1995.

[77] Y. Sun, Q. Yue, Y. Mao, B. Gao, Y. Gao, and L. Huang, "Enhanced adsorption of chromium onto activated carbon by microwaveassisted $\mathrm{H}_{3} \mathrm{PO}_{4}$ mixed with $\mathrm{Fe} / \mathrm{Al} / \mathrm{Mn}$ activation," Journal of Hazardous Materials, vol. 265, pp. 191-200, 2014. 

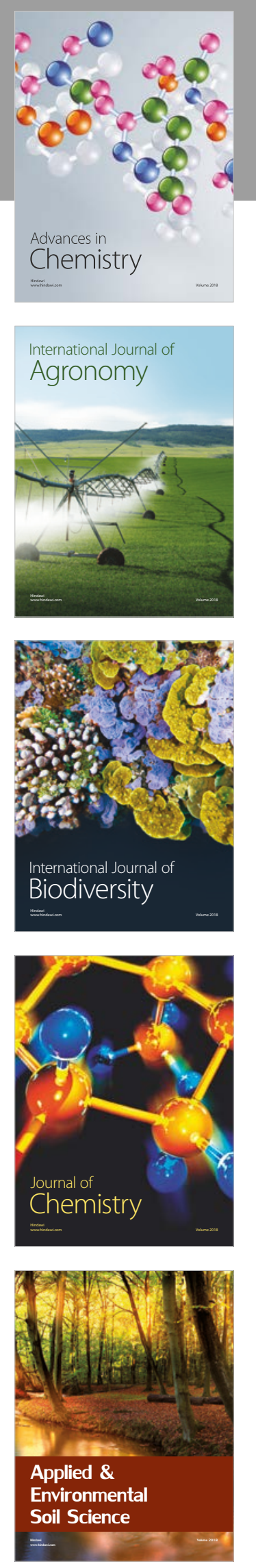

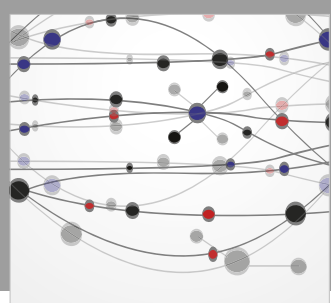

The Scientific World Journal

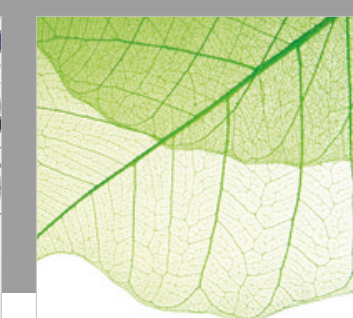

Journal of Botany

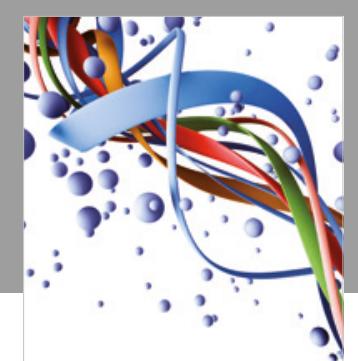

Scientifica

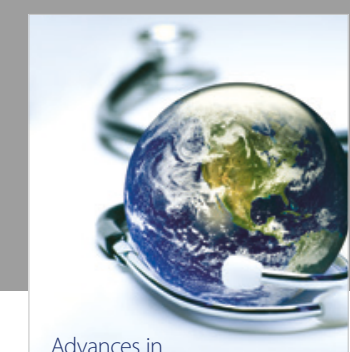

Public Health

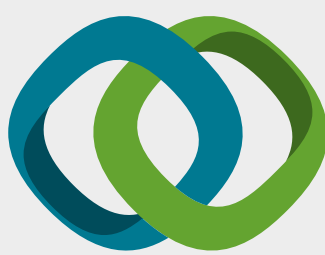

Hindawi

Submit your manuscripts at

www.hindawi.com
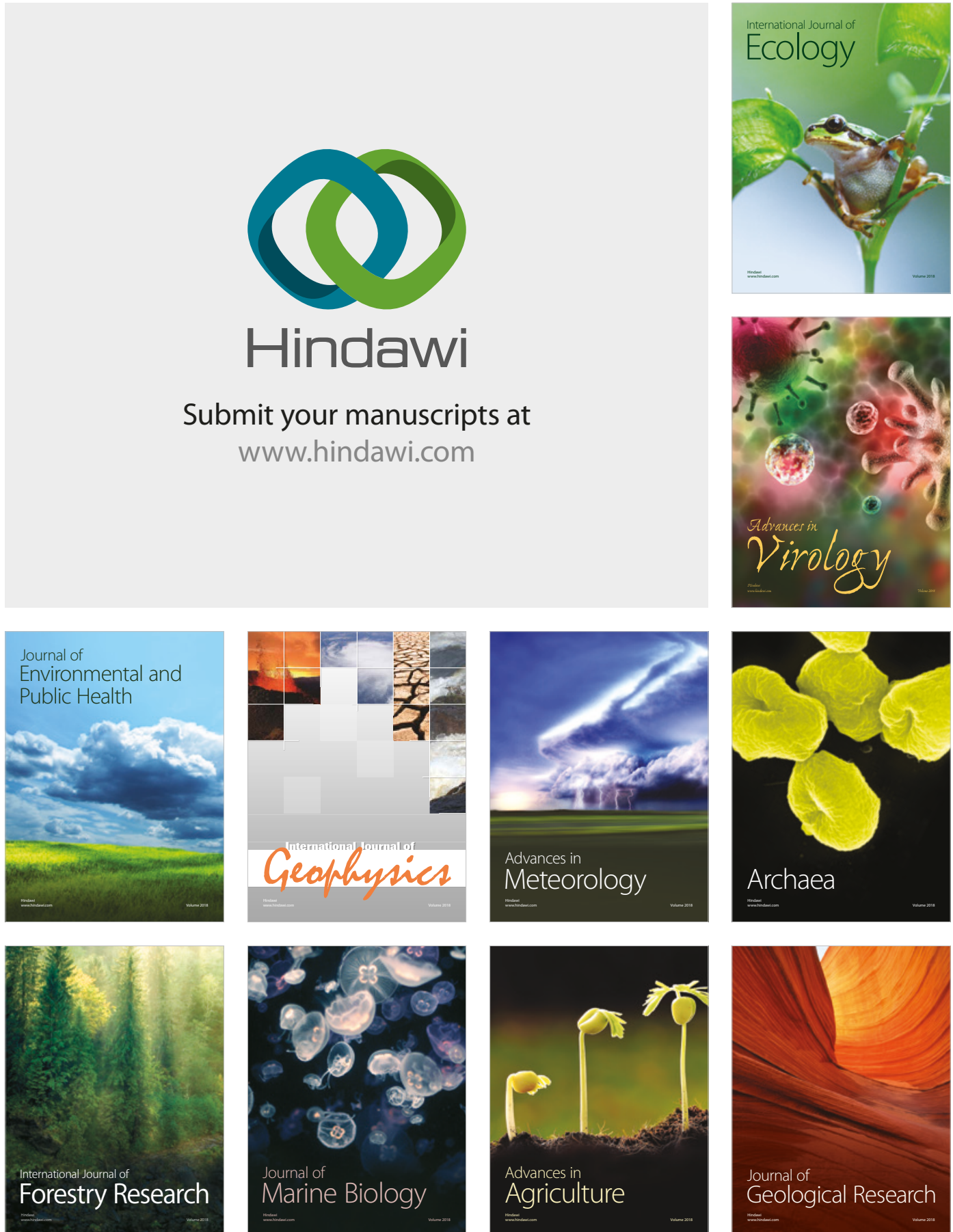

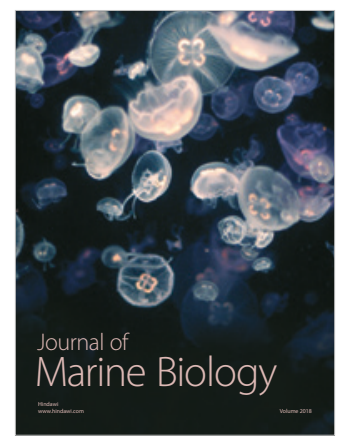

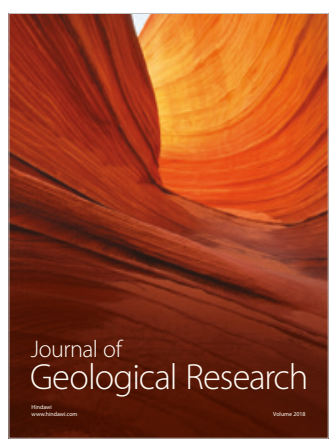

